\title{
Reading the Preamble to the BRITISH NORTH AMERICA ACT, 1867
}

\section{S.M. Corbett}

"The only means of retaining distant colonies with advantage is to enable them to govern themselves."

Charles James Fox, $1791^{1}$

"What does 'promote the interests of the British

Empire' mean in law?"

$$
\text { F.R. Scott, } 1960^{2}
$$

References to the Preamble to the British North America Act, 1867 (now the Constitution Act, 1867) typically emphasize the first of the four recitals. ${ }^{3}$ That recital sets out the federal basis of the desired union and establishes "a Constitution similar in Principle to that of the United Kingdom." 4 As a result of the enactment of this statute the Provinces of Canada (Upper and Lower), New Brunswick and Nova Scotia joined together with the United $\mathrm{K}$ ingdom to create a new political entity also called "Canada." The first recital says what is being done, the second recital tells us why. In this second recital reference is made to "the Welfare of the

This remark was made during the debate over the Quebec Act in the British Parlia ment. See Lord John Ru ssell, The Life and Times of Charles James Fox, vol. II (London: Richard Bentley, 1859) at 251.

2 F.R. Scott, Essays on the Constitution (Toronto: University of Toronto Press, 1977) at 358.

3 The Constitution Act, 1867 (U.K.), 30\&31 Vict. c. 3. The 1867 Preamble reads:

WHEREAS the Provinces of Canada, Nova Scotia, and New Brunswick have expressed their Desire to be federally united into One Dominion under the Crown of the United Kingdom of Great Britain and Ireland, with a Constitution similar in Principle to that of the United Kingdom:

AND WHEREAS such a Union would conduce to the Welfare of the Provinces and promote the Interests of the British Empire:

AND WHEREAS on the Establishment of the Union by Authority of Parliament it is expedient, not only that the Constitution of the Legislative Authority in the Dominion be provided for, but also that the Nature of the Executive Government therein be declared:

AND WHEREAS it is expedient that Provision be made for the eventual Admission into the Union of other Parts of British North America.

4 Ibid.
Provinces" and "the Interests of the British Em pire." By virtue of the passage of the British North America Act, the meaning of the name "Canada" changed. Rather than marking a new beginning, the British North America Act marked a transition point, a change in the direction of colonial administration, not a wholesale rejection of the project of imperialism. While Canada was no longer just a colony after 1867 it is equally true that Canada was not a fully sovereign state. The new "C anada" came into existence at the meeting point of two sets of interests, those of the original Provinces and those of the British Empire. ${ }^{6}$ Both of these interests must be taken into account in any attempt to discern the intentions lying behind the Act which created $\mathrm{C}$ anada.

In Reference re Remuneration of Judges, Chief Justice Lamer returns to the Preamble to The Constitution Act, 1867 in search of a secure grounding for the institutional independence of all levels of the judiciary. ${ }^{7}$ Echoing Scott he notes that the "legal effect (of the Preamble) has never been fully ex plained." ${ }^{8} \mathrm{He}$ proceeds to argue on the basis of principles of statutory construction that, like preambles in general, it "can be

Even when the Preamb le is quoted at greater len gth the first recital receives judicial atten tion. Mo reover, when the se cond recital is noted, as in the dissent by Martland and Ritchie JJ. in the Constitution Reference, only the reference to the welfare of the Provinces is used in the ensuing decision. See Reference re Amendment of the Constitution of Canada (1982) 125 D.L.R. (3d) 1 at 54 .

The debate between those who favoured the creation of a unitary state, primarily the representatives of Upper Canada, and those who favoured a looser confederation, representatives of Lower Canada and the Maritimes, is well known.

Reference re: Public Sector Pay Reduction Act (PEI), s. 10; Reference re: Provincial Court Act (PEI); R. v. Campbell; R. v. Ekmecic; R. v. Wickman; Manitoba Provincial Judges Assn. v. Manitoba (Minister of Justice), [1997] 3 S.C.R. 3, (1997) 150 D.L.R. (4th) 577 (S.C.C.), para. 83 (hereinafter Reference re Rumuneration of Judges). Since the Reference concerned the remuneration of Provincial Cou rt Judges it raises, by implication, the question of $\mathrm{w}$ hether $\mathrm{C}$ anada has a unified ju dicial syste $\mathrm{m}$; in other words, do the terms 'court' and 'judge' have the same meaning in the Provincial and the Superior courts?

Lamer C .J., Reference re Remuneration of Judges, para. 94. 
used to identify the purpose of (the British North America Act, 1867) and as an aid to construing ambiguous .... language." 9 He quotes Rand J. to the effect that "the preamble articulates "the political theory which the Act em bodies." ${ }^{10}$ The idea that the Preamble contains a "political theory" which can be used "to identify the purpose" of the British North America Act and that this "theory" and "purpose" defines the current role of the judiciary in the Canadian constitutional order is, to say the least, somewhat surprising. ${ }^{11}$ While Lamer C.J. recognizes the evolutionary nature of the Canadian constitution, rather than seeing the place of the Canadian judicial system within the present constitutional order as the historically contingent product of that evolution, he seeks to locate the theory which grounds that order in a document which created a system significantly different from the one which exists today. According to the Chief Justice the current order has been derived from the original document by a "process of gap-filling." 12 On this view the current order is the unfolding of the original order, the actualisation of intentions which can be read into a founding, rather than the result of a series of historically conditioned political choices made in response to changing circumstances, most notable among which is the demise of the British Empire.

When F.R. Scott asked his question in 1960, the sun was already well down on the horizon. By 1998 the sun has all but set. Yet the consequence s of British, or, more broadly, Europea n, imperialism continue to define much of the political structure of the contemporary world. The shadows cast by the setting sun can be very long indeed. They have proven to be especially long in Canada. They are, nonetheless shadows; Canada has chan ged dram atically since 1867 in almost every respect imaginable. Typically the fact of historical change raises the difficult question of how to read a document which, like all documents, was a product of a particular time and place. The difficulty is especially acute when the purpose of reading the document is not just to better understand the past but rather to seek guidance in the present. Unlike

\footnotetext{
$9 \quad$ "As such, the preamble is not only a ke y to construing the express provisions of the Constitution Act, 1867 , but also invites the use of those organizing principles to fill out gaps in the express terms of the constitutional scheme. It is the means by which the underlying logic of the A ct can be given the force of law."

Lamer C .J., Reference re Remuneration of Judges, para. 95.

${ }^{10}$ Lamer C .J., Reference re Remuneration of Judges, para. 95.

11 In his dissent, L aForest J. a lso takes issue with the claim that the Preamb le contains a theory of government: "In other words, the approach adopted by the Chief Justice, in my view, misapprehends the nature of the Constitution Act, 1867. The Act was not intended as an abstract document on the nature of government." Justice LaForest also recognises the importance of placing the Constitution Act, 1867 within the context of the British Empire. See LaFores t J., Reference re Remuneration of Judges, para. 320.

12 Lamer C.J., Reference re Remuneration of Judges, para. 97.
}

images on coins and flags, which continue to remind us of our historical ties to the interests of British imperialism and whose meaning is purely symbolic, the text of a constitution is used to confer legitimacy on the behaviour of various political actors in the present. In 1867 the British Empire served the interests of the United Kingdom through the enterprise of colonialism. Questions of legitimacy arose with in the context of that enterprise. Coins, flags, and oaths were symbols of the role played by Canada in the pursuit of those interests. The Prea mble gave expression to those same interests. In light of the demise of those interests it must, therefore, be approached in the present with a good deal of caution. While it does tell us som ething about the origins of the Canadian constitutional order, it is no means the definitive statement of that order, nor, for that matter, is the whole of the Constitution Act, 1867.

The sense in which Can ada ever had a constitution similar in principle to that of the United Kingdom is, and should be, a matter of debate. Unlike the Canada of 1867, or the United Kingdom of 1867 (or of 1998 for that matter), Canada now has an entrenc hed Charter of Righ ts and Freedoms. In addition, unlike the United Kingdom of 1867 or 1998 , Canada has a well established practice of judicial review of legislation. In part due to these features of the present constitutional order we no longer have, if indeed we ever did, a constitution which could be described without a good deal of qualification as being "similar in Principle to that of the United Kingdom." The federal nature of the union clearly distinguished Canada from the United Kingdom at the outset. Indeed, Lamer C.J. himself notes that "(the) institutional independence of the courts emerges from the logic of federalism, which requires an impartial arbiter to settle jurisdictional disputes between the federal and provincial orders of governm ent." This, however, is o nly half the story. The current position of the courts within the Canadian constitutional order must be understood not only as the result of our original establishment as a federal system, but also as one of the consequences of that establishment within the larger context of the British Empire. This context is the source of a further difference between the constitutions of Canada and the United Kingdom. One of the defining features of the constitution of the United Kingdom is the supremacy of Parliamen . $^{13}$ The Canadian

\footnotetext{
"Under accepted British legal theory, Parliament is supreme. By this I mean that there are no limitations upon its legislative competence. As Dicey explains, Parliament has "under the English constitution, the right to make or unmake any law whatever; and further that no person or body is recognised by the law of England as having a right to override or set aside the legislation of Parliament"' (A. V. Dicey, The Law of the Constitutio n, 10th ed., (1959) at 39-40). See LaFores t J., Reference re Remuneration of Judges, para. 308.
} 
Parliament has never been supreme. From 1867 to 1949 there were at least three checks on parliamentary supremacy, the Royal prerogative, still symbolised in Canad a in the office of the Governor General, the power of the British Parliament to alter the British North America Act, and the role of the Judicial Committee of the Privy Council as Canada's highest appellate court. Furthermore, the federal nature of the union meant that the federal and the provincial legislatures could each be understood as a check upon the supremacy of the other. These various checks on parliamentary suprem acy were linked because, while it may be true to say that the logic of federalism required "an impartial arbiter," once that was accepted the logic of imperialism located that arbiter in the United Kingdom. While the authority of the British Parliament and the Judicial Committee of the Privy Counc il was seriou sly weak ened in 1931, and the role of the latter was eliminated in 1949, it wasn't until 1982 that the final step was taken toward making a complete break with the British parliament. ${ }^{14}$

In 1949 the final authority for constitutional judicial review of federal and provincial legislation became vested in the Supreme Court. This was not a necessary transition. Following the discontinuation of appeals to the Judicial Co mmittee the role of dom estic courts could have been brou ght into line with the role of the courts in the United Kingdom. That this did not happen is a well established fact in the history of the development of the Canadian constitutional order. Since the 1950s the courts have regularly adjudicated disputes between the provinces and the federal government. In addition to adjudicating disputes arising under sections 91 and 92 they have also used section 96 to challenge the power of provinciallegislatures, most significantly in the series of cases originating in the decision of the Judicial Comm ittee in John East Ironworks. ${ }^{15}$ These latter cases, originally hybrids of federal and judicial issues, have led to more recent decisions in which the jurisdiction of the federal parliament also has been checked by the courts. ${ }^{16}$

14 The idea that the courts are involved in a "process of gap-filling" would seem to require a co nstitution which is not s imilar to that of the United Kingdom. Thus when the Chief Justice writes that " $[\mathrm{t}]$ he preamble identifies the organizing principles of the Constitution Act, 1867, and invites the courts to turn those principles into the prem ises of a constitutional argument that culminates in the filling of gaps in the express terms of the constitutional text," this 'invitation' is at odds with the idea of "a Constitution Similar in Principle to that of the United Kingdom" insofar as it recognises constitutional supremacy rather than parliamentary suprem acy and grants to the courts the a uthority to say what the constitution means. See Lamer C. J., Reference re Remuneration of Judges, para. 104.

15 Saskatchewan (Labour Relations Board) v. John East Iron Works Ltd., [1949] S.C.R. 677.

16 MacMillan Bloedel v. Simpson, [1996] 2 S.C.R. 1048; 140 D.L.R. (4th) 385 (hereinafter MacMillan Bloed el).
This line of cases, which now spans half a century, is directly relevant to the reading of the Preamble for at least three reasons. First, the cases are concerned with defining the role of the courts within the Canadian constitutional order; second, they not only illustrate the extent to which that role has changed since 1867, they are themselves an essential part of the process of change, one of those places within constitutional jurisprudence where members of the judiciary have bee $n$ called up on to reflect upon their own role within the constitutional order; and, third, the most recent cases in the series, MacMillan Bloedel v. Simpson and Bell v. Canada (Canadian Human Rights Commission); Cooper v. Canada (Canadian Human Rights Commission) contain reasons written by Lamer C.J. which are directly related to his reading of the Preamble in Reference Re Remuneration of Judges. ${ }^{17}$

The cases originally involved challenges to the authority of provincial governments (the federalism aspect) to create administrative bodies exercising adjudicative functions (typically dispute resolution, including the provision of remedies, and the hearing of appeals) within jurisdictions which may, or may not, have been occupied by the superior, or section 96 , c ourts at the time of Confederation (the judicial as pect). The cases arose in the context of federalism because section 96 of The Constitution Act, 1867 confers authority for the appointment of superior court judges upon the federal governm ent. This meant that any attempt by a provincial legislature to confer judicial functions upon an administrative tribunal could be understood as an encroachment upon federal jurisdiction if the body in question was exercising that function within a legal jurisdiction occupied by the section 96 courts in 1867 . While these cases do not fit the standard model of federalism cases involving disputes over the division of powers set out in sections 91 and 92 of The Constitution Act, 1867 they form, nonetheless, part of the larger fabric of federalist jurisprudence. The most influential of these cases, Residential Tenancies (Ontario) and Sobey's Stores created a framework (the Residential Tenancies test) within which the courts could evaluate the extent to

Bell v. Canada (Canadian Human Rights Commission); Cooper v. Canada (Canadian Human Rights Commission), [1996] 3 S.C.R. 854; 140 D.L.R. (4th) 193 (hereinafter Cooper). While Lamer C.J. wrote the majority judgment in MacMillan Bloedel he concurred with the decision of the majority in Cooper and wrote his own reasons. In Reference Re Remuneration of Judges he cites a passage from his reasons in Cooper regarding the link between the independence of the judiciary and the separation of powers. Significantly, for reasons I hope will become clear, the passage in Cooper also contains a reference to the idea of 'core jurisdiction' set out in MacMillan Bloedel v. Simpson. See Lamer C. J., Reference re Remuneration of Judges, para. 125 ; Cooper D.L.R. 201-2; MacMillan Bloed el S.C.R. 753. 
which encroachment upon the traditional role of the courts by statutory administrative bodies was permissible. ${ }^{18}$ Following the precedent set by the Judicial Committee in John East Ironworks the courts used an historically situated reading of the meaning of section 96 to justify their authority for policing their own boundaries. This meant that the legislatures, initially provincial but eventually the federal Parliament as well, had to justify to the courts any encroachment upon a jurisdiction which, in the courts' opinion, had been granted to them in 1867 by the use of the word 'court' in section 96. Thus, the Canadian constitution was read as having established a permeable barrier between the legislature and the judiciary, a barrier whose degree of permeability was, however, to be determined by the judiciary. In MacMillan Bloedel, Lamer C.J., writing for the majority, argued that there are limits to the permeability of the barrier, limits which cannot be crossed by the provincial legislatures or the federal Parliament. These lim its are collective ly characterised as the 'core jurisdiction' of the section 96 courts. As in the earlier cases, which focussed upon the problem of defining a 'judicial function,' it is up to the courts to determine what actually falls within their core. ${ }^{19}$ If the courts do indeed possess the authority to de fine what a court is, that is to say, the power to determine the ir own role within the constitutional order, then it is a matter of more than passing interest how they go about performing this task.

18 The Residential Tenancies test was first articulated by Dickson J. (as he then was) in Reference Re ResidentialTenancies Act, [1981] 1 S.C.R. $714 ; 123$ D.L.R. (3d) 554. As originally formulated the test involved three steps each of which must be failed for a tribunal to be found ultra vires. The three steps may be briefly summarised as follows: first, does "the particular power or jurisdiction conferred upon the tribunal ... (conform) to the power or jurisdiction exercised by Superior, District or County Courts at the time of Confederation;" second, if so, does the function remain essentially 'judicial' within its new institutional setting, and; third, if it does, to what extent is the function integrated with the larger administrative functions of the tribunal? The first, or historical, step was significantly expanded by Wil son J. in he r judgm ent in Sobeys Stores Ltd. v. Yeomans and Labo ur Standards Tribunal (NS) [1989] 1 S.C.R. 238; 57 D.L.R. (94th) 1.

19 In her dissent in MacMillan Bloedel MacL achlin J. argues against the introduction of a 'core jurisdiction test.' She distinguishes between legislative initiatives which "threaten the constitutional position of the s. 96 courts" and the idea of a "core jurisdiction" which she believes "would impose significant new restrictions on the power of Parliament and the legislatures." If it is up to the courts to decide when their "constitutional position" has been threatened then this may be a distinction without a difference unless the courts are prepared to recognize that their position within the constitutional order, like that of the legislature and the executive, is subject to change over time. Indeed, McLachlin J. recognizes this when she writes that the Residential Tenancies test "has developed over the past fifty years in response to the changing social co nditions of this country" (D.L.R.. 412).
The jurisprudence flowing from John East illustrates the difference between what might be called 'reading the constitution historically,' on the one hand, and 'reading the constitution as a history,' on the other. When reading a constitution historically one attempts to locate the meaning of the constitution within the broader historical context in which it was written. This may be done either by attending to the meaning that the words and phrases would have carried in that context or, more ambitiously, by attempting to identify the intentions of those who used the words and phras es. Each of these approaches is fraught with difficulties because words and phrases are rarely precise enough to carry a single meaning and the intentions underlying their use are even more difficult to define. Constitutions, like statutes, are the products of negotiations. The resulting document rarely expresses a single point of view. Thus, by attempting to locate the meaning of the word 'court' in 1867 (or in 1701) the courts have endeavoured to fix that which cannot be fixed. ${ }^{20}$ While reading a constitution as a history also requires attending to the historical context in which the document was written it also involves recognizing both the changing historical context within which subsequent attempts to interpret the document must be made as well as the contribution to that context made by prior interpretations of the document in question. In other words, the court which is interpreting the Constitution Act, 1867 in 1997 is not only situated in a different historical context than the authors of the British North America Act, 1867 but its place within that context has been shaped by the prior interpretations of courts operating in changing historical contexts.

When read as a history, the jurisprudence evidences the development of a doctrine of the constitutional separation of powers between the courts and the other two branches of government. The power of the courts to define their own role on the basis of their reading of the constitution is not, however, a separation of powers on the model of the United States because Canada remains wedded to the Westminister model of ministerial responsibility, one of the ways in which the Canadian constitutional order does resemble that of the United Kingdom, albeit a resemblance now significantly weakened by the existence of the Charter of Rights and Freedoms. ${ }^{21}$ Thus, when Lamer C.J. takes the further step

20 In this regard the following remark by J.H. Baker is apropos: "our present image of a 'court' is the outcome of history, not the reflection of some constant truth which transcends history." See J.H. Baker, "T he Chan ging Concept of a Court" in The Legal Profession and the Common Law (London: The Hamb ledon Press, 1986) at 153.

21 There is another importan t way in which Canadian courts are not separate in the sense in which their Am erican cou nterparts are. In Canada the administration of the courts falls under the authority of the executive branch of government. In effect the executive 
of affirming that "the institutional independence of the judiciary reflects a deeper commitment to the separation of powers between and amongst the legislative, executive, and judicial organs of government" this commitment cannot be read into the Preamble. ${ }^{22}$ The relation between an imperial court and legislatures subject to its supervision in the interest of Empire cannot be used to provide a theoretical foundation for the separation of court and legislature within a domestic constitution. $^{23}$ If Canada has moved, and is moving, toward a constitutional order in which the courts are increasingly separate from the other two branches of government, then this must be understood as the contingent historical consequence of the actions of those who wrote the Preamble to the British North America $A c t$, rather than as the actualisation of their intentions. ${ }^{24}$ The Canadian constitution, as Section 52 of the Constitution Act, 1982 makes abund antly clear, must be read not just historically, it must be read as a history. ${ }^{25}$

Chief Justice Lamer also recognises, not surprisingly, that "(i)nstitutional inde penden ce inheres in adjudication under the $\mathrm{Charter}$, because the rights protected by that document are rights against the state." ${ }^{26}$

provides the setting within which the judges fulfill their constitutionally assigned roles.

22 Reference re Remuneration of Judges, para. 125 (empha sis added).

23 In his dissent LaForest J. also recognises the importance of reading The Constitution Act, 1867 with reference to the relation between Britain and Canada at the time of Confederation. "The philosophical underpinnings of government in a British colony were a given, and find expression in the preamble. The Act was intended to create governmental and judicial structures for the maintenance of a British system of government in a federation of former British colonies. Insofar as there we re limits to legislative power in Canada, they flowed from the terms of the Act (it being a British statu te) that create $d$ them a nd vis-à-v is Great B ritain the condition of dependency that prevailed in 1867 . In considering the nature of the structures created, it was relevant to look at the principles underlying their British counterparts as the preamble invites the courts to do." See Reference re Remuneration of Judges, para. 325.

24 I am not arguing for or against the idea of the separation of the judiciary from the other branches of government. Indeed, a strong case for separation might be made in the context of rights adjudication under the Charter. My point is the narrower one that such a doctrine cannot be read into the Preamble.

25 It could be argued, with some justification, that the evolutionary nature of the Canadian constitution derives from Canada's common law heritage. While this would retain the link with the United Kingdom it would not prese rve the principle of Parliamentary supremacy. On the contrary, it would further highlight the role of the courts in the Canadian constitutional order since the constitution has been subject to interpretation by common law courts from the beginning. On such an ac count on e would expect to see emerging over time a distinctively Canadian jurisprudence rooted in the courts' attempts to deal with issues arising from the division of powers and,more recently, the Charter of Rights and Freedoms. This result would not, of course, be what has been called 'the Commo n Law Constitution.'

${ }^{26}$ Reference re Remuneration of Judges, para. 124.
In 1982 the role of the courts was extended because of the introduction of the Charter. While the introduction of the Charter may justifiably be said to have expanded the role of the courts within the constitutional order, it did not fundamentally alter the orderitself; this new role was not created ex nihilo in $1982 .{ }^{27}$ The courts were able to assume their altered role because for a period spanning more than a century they had been actively involved in the review of legislation on constitutionalgrounds. Since this new role is significantly different than the role played by the British courts in 1867 it is difficult to derive a theoretical justification for the current role of the Canadian courts from the first paragraph of the Preamble. On the other hand, if we derive that role from the combined effect of the first two paragraphs then we must recognize that the reference to the interests of the British Empire in the second paragraph, while providing the beginning point for an historical account of the evolution of the Canadian courts, no longer provides a conceptual foundation for their current role. This is not to suggest, however, that we should abandon our collective fate to the forces of history and refrain from the search for such a foundation. On the contrary, it is to recognize that any such quest can only be undertaken by the living, by individuals whose differing opinions regarding what might constitute such a foundation will be informed, not only by competing political ideals, but also by politically charged interpretations of the past. There are, how ever, certain historical changes which are not open to rational debate. The demise of the British Empire would appear to belong unquestionably to this category.

It is a commonplace of constitutional interpretation that one must strike a balance between stability and change. Yet, stability need not mean stasis and change need not mean disorder. Stability is to be found not in maintaining certain structures as constants over time but, rather, in understanding the structure of the changes which have occurred over time. This structure does not determine our future. To perceive it in this way would be to deny our own responsibility for that future while tying us to the choices and compromises of those who have gone before, choices and compromises made in significantly different circumstances. Any attempt to fix the constitutional order at a particular point in time means that we must privilege the beliefs and actions of individuals who happened to be alive at that point in

27 Insofar as individuals were able to bring actions against both Federal and Provincial gov ernments und er the division of pow ers it can be argued that the introduction of the Charter simply broadened the basis for such actions. While this would undoub tedly ove rsimply the issues invo lved it is imp ortant not to lose sight of the fact that the courts had been involved in adjudicating disputes between citizen and government on constitutional grounds lo ng before the adv ent of the Charter. 
time, thereby elevating them to a place outside history while diminishing our own cap acity to contribute to the ongoing project of constitutional ordering. However, although we are not bound by the intentions of our predecessors we do, nonetheless, live in a world partially created by those intentions. The choices and compromises of our predecessors are the sources of the institutions from within which we are able to confront the present and imagine the future. ${ }^{28}$ At any given point in time the constitution provides us with a relative ly stable framework within which to conceptualise change, changes which may, in time, subtly, or given sufficient time, dramatically, alterthe framewok itself. At this point in our history the presence of the word 'Canada' twice in the Preamble with two different meanings is far more significant than references to the United Kingdom and the British Empire. Canada lacks a foun ding mom ent; it also lacks a founding myth. Some have seen this as the fatal flaw in the Canadian project. It may, however, be our greatest strength. As I noted at the outset, Canada did not come into being in 1867 , it changed. The Canadian constitution is the story of a series of such transitions, transitions which stop short of radical transformations. That some of these transitions have undeniably been more important than others does not take away from the fact that they too were transitions.

As we struggle to get our bearings following the end of European hegemony, a struggle made all the more difficult by the rise to global dominance of our next door neighbour, it is inevitable that in the search for a new direction we may look to the past for signs of continuity. The past may be interpreted as telling us who we are, defining us in terms of stable traditions whose preservation becomes the object of our future. If what we seek is a national identity this use of the past may seem appealing. We cherish the things that define us precisely because they define us. Morality, including political morality, is retumed to its origins in custom. On the other hand, reference to the past may reveal to us how much we've changed, thereby opening up the difficult question of whether such change has been good or bad. Are we better than we were, worse, or just different? If the present century has made us mistrustful of dreams of national destiny and the related myths of entitlement, we must be open to the possibility that we, like others, must find new ways of living in a world which has changed radically in the past one hundred and thirty years. Moreover, given that it might now be more accurate to state that the United Kingdom is moving toward adopting a Constitution similar in principle to that of Canada, rather than trying to a nchor our political institutions in references to the United Kingdo m of 1867 , it is time to recognize that we may have made and may still be capable of making a valuable contribution to the problem of constitutional ordering. Who knows, from some future vantage point this may yet turn out to have been Canada's century.

\section{S.M. Corbett}

Faculty of Law and Department of Philosophy, Queen's University.

28 That these choices and compromises can also come to be characterised by subsequent generations in the lang uage of victory and defeat, or pride and shame, thereby removing the element of compromise, is, of course, also true. The history of constitutional ordering can never be read independently of the broader historical context within which that ordering occurs. In deed, to attempt do so would be to blind oneself to the circumstances which gave meaning and purp ose to the $\mathrm{c}$ hoices an $\mathrm{d}$ comp romises $\mathrm{w}$ hic are the source of the order. 